\title{
Distribution and reproduction of the Arctic ctenophore Mertensia ovum in the Baltic Sea
}

\author{
Maiju Lehtiniemi ${ }^{1, *}$, Elena Gorokhova ${ }^{2}$, Sören Bolte ${ }^{3}$, Holger Haslob ${ }^{4}$, \\ Bastian Huwer ${ }^{5}$, Tarja Katajisto ${ }^{1}$, Lennart Lennuk ${ }^{6}$, Sanna Majaneva ${ }^{1}$, \\ Arno Põllumäe ${ }^{6}$, Matthias Schaber ${ }^{4}$, Outi Setälä ${ }^{1}$, Thorsten B. H. Reusch ${ }^{3}$, \\ Satu Viitasalo-Frösén ${ }^{1}{ }$ Ilppo Vuorinen ${ }^{7}{ }^{1}$ Pentti Välipakka ${ }^{8}$ \\ ${ }^{1}$ Finnish Environment Institute, Marine Research Center, PO Box 140, 00251 Helsinki, Finland \\ ${ }^{2}$ Department of Applied Environmental Science \& Department of Systems Ecology, Stockholm University, 10691 Stockholm, Sweden \\ ${ }^{3}$ Helmholtz-Centre for Ocean Research (GEOMAR), Evolutionary Ecology of Marine Fishes, Düsternbrooker Weg 20, \\ 24105 Kiel, Germany \\ ${ }^{4}$ Johann Heinrich von Thünen-Institute, Federal Research Institute for Rural Areas, Forestry and Fisheries, \\ Institute of Sea Fisheries, Palmaille 9, 22767 Hamburg, Germany \\ ${ }^{5}$ Technical University of Denmark, National Institute of Aquatic Resources, Charlottenlund Castle, Jægersborg Allé 1, \\ 2920 Charlottenlund, Denmark \\ ${ }^{6}$ Estonian Marine Institute, University of Tartu, Mäealuse 14, 12618 Tallinn, Estonia \\ ${ }^{7}$ Archipelago Research Institute, University of Turku, 20014 Turku, Finland \\ ${ }^{8}$ Centre for Economic Development, Transport and the Environment for Southeast Finland, PO Box 1041, 45101 Kouvola, Finland
}

\begin{abstract}
Species identification based on morphological characteristics has caused misidentifications and led to twisted views of abundances and roles of ctenophores. Based on extensive field studies from 2007 to 2010, the occurrence of the arctic ctenophore Mertensia ovum was genetically verified in the southern, central and northern Baltic Sea, and its egg production, distribution and abundance were studied in relation to physical factors. Genetic analyses indicate that $M$. ovum is by far the most abundant small ctenophore in the Baltic Sea. Specimens from a $20 \mathrm{yr}$ old ctenophore collection were also genetically identified as M. ovum, contrary to their previous morphological identification as another ctenophore species, Pleurobrachia pileus. Thus, earlier reports on $P$. pileus in the Baltic Sea may actually refer to $M$. ovum. The abundance of $M$. ovum was regulated by both salinity and temperature, with highest abundances found in sea areas and water layers at temperatures $<7^{\circ} \mathrm{C}$, salinities $>5.5$ and oxygen levels $>4 \mathrm{ml} \mathrm{l}^{-1}$. During summer, the highest abundances of ctenophores and their eggs were found near the halocline, while the distribution was more uniform throughout the water column during winter. Only ctenophores $>3.5 \mathrm{~mm}$ (oral-aboral length) produced eggs in the experiments, with an average rate of 2.2 eggs ind. ${ }^{-1} \mathrm{~d}^{-1}$. Finally, comparison with published data from the 1980s (assuming that those data refer to $M$. ovum) indicates that the present-day ctenophore abundance is $~ 80 \%$ lower in the north and $~ 55 \%$ higher in the southern parts of the Baltic Sea, due to reasons yet to be established.
\end{abstract}

KEY WORDS: Mertensia ovum - Pleurobrachia pileus · Identification · Abiotic factors · Egg production

Resale or republication not permitted without written consent of the publisher

\section{INTRODUCTION}

Although jellyfish aggregations are natural phenomena in healthy pelagic ecosystems (Graham et al.
2001), their occurrence has been increasing around the world (Richardson et al. 2009, Brotz et al. 2012). However, due to lack of long term data, this global increase of gelatinous zooplankton has been recently 
questioned (e.g. Condon et al. 2012). The 'increase' may at least partly be explained by increased attention by the media and by natural population cycles (Condon et al. 2012). Unfortunately, reliable data on jellyfish abundances are difficult to obtain (but see e.g. Mutlu et al. 1994 for the Black Sea), because gelatinous zooplankton individuals are fragile and thus difficult to sample and preserve. This hampers regular monitoring, collection of time series data and maintenance of sample archives. Analysis of population dynamics and abundance fluctuations of gelatinous zooplankton is challenging but possible to do if proper sampling gear and appropriate procedures are utilized (e.g. Riisgård et al. 2012).

There are only few species of jellyfish (Cnidaria) and comb jellies (Ctenophora) in the Baltic Sea, which is characterized by a strong salinity gradient from nearly fresh water in the coastal areas of the northern and eastern parts to nearly marine water in the west (in close proximity to the North Sea). According to earlier reports, Pleurobrachia pileus (Cydippida) was the only ctenophore present throughout the Baltic Sea, except for the most oligohaline areas (e.g. Mielck 1926, Ackefors 1969, Vuorinen 1987). In the southern and western parts of the Baltic, 4 other ctenophore species may occur: Bolinopsis infundibulum (Lobata), Beroe cucumis, B. gracilis (Beroidea), and a recent invader to the Baltic Sea, the American comb jelly, Mnemiopsis leidyi (Lobata) (e.g. Hansson 2006). While M. leidyi has also been reported in the northern Baltic Sea (Lehtiniemi et al. 2007, Viitasalo et al. 2008), these ranges were based on misidentification of the morphologically similar (as a larva) cydippid ctenophore Mertensia ovum, previously unknown in the Baltic Sea (Gorokhova et al. 2009). However, M. leidyi occurs regularly as far east as the Bornholm Basin as verified by genetic analyses (Schaber et al. 2011). These findings prompted us to conduct a thorough survey of gelatinous zooplankton in the Baltic Sea, using appropriate sampling gear (e.g. a $\leq 500 \mu \mathrm{m}$ mesh net to be able to sample small individuals), and increased spatial and temporal sampling coverage.

There is a great difference in body size range between Mertensia ovum found in the Arctic Ocean (1 to 89 mm; Matsumoto 1991, Swanberg \& Båmstedt 1991, Lundberg et al. 2006) and those found in the Baltic Sea (0.5 to $7 \mathrm{~mm}$; Gorokhova et al. 2009), making it impossible to extrapolate basic life history traits for the Baltic populations, such as size at first reproduction and egg production rate, using size data from the Arctic populations. For this reason, both field data and laboratory measurements are a prerequisite to understanding the biology of this species in the Baltic Sea. From an ecological and phenotypic plasticity perspective, the Baltic $M$. ovum is interesting because there are no records of this species being found in other low salinity environments. Last century, all ctenophores were assumed to be Pleurobrachia pileus since this was thought to be the only ctenophore species present in the northern Baltic Sea (Ackefors 1969). Given the discrepancy between earlier reports (e.g. Mielck 1926, Vuorinen 1987) and recent genetic evidence that no ctenophores other than $M$. ovum were present in the northern Baltic Sea in 2008 (Gorokhova et al. 2009), the question arises: What has happened to $P$. pileus in this ecosystem?

The objectives of this study were to (1) determine Mertensia ovum distribution and abundance in the Baltic Sea in different seasons and water depths; (2) assess egg production rates and size at first reproduction of M. ovum; and (3) genetically re-identify ctenophores collected in 1990 in the Bothnian Sea originally identified as Pleurobrachia pileus (P. Välipakka unpubl. data). (4) Based on our re-identification results and assuming that historical records of $P$. pileus in the Baltic Sea actually refer to M. ovum, we used abundance data and ctenophore size distributions for the 1980s and 1990s from the literature as well as from the present study to evaluate changes in M. ovum standing stocks during the last $>20 \mathrm{yr}$ and relate the changes to salinity differences between the periods in question.

\section{MATERIALS AND METHODS}

\section{Sampling for distribution and abundance of ctenophores}

Between 2007 and 2010, we sampled ctenophores during 49 monitoring and research cruises throughout the Baltic Sea (Table 1, Fig. 1a). Data (P. Välipakka unpubl.) that had been collected during 15 cruises in the early 1990s using similar sampling techniques (vertical net hauls) and abundance analysis (counting specimens alive onboard) (Table 1) and data compiled from published papers in the Gulf of Bothnia (Vuorinen 1987, Vuorinen \& Vihersaari 1989) were also included.

Most of the samples in our study were obtained during the daytime with vertical net hauls $(500 \mu \mathrm{m}$ mesh size or smaller) (see Table 1 for sampling details). The ctenophores collected on research cruises were counted alive onboard using a dissecting micro- 


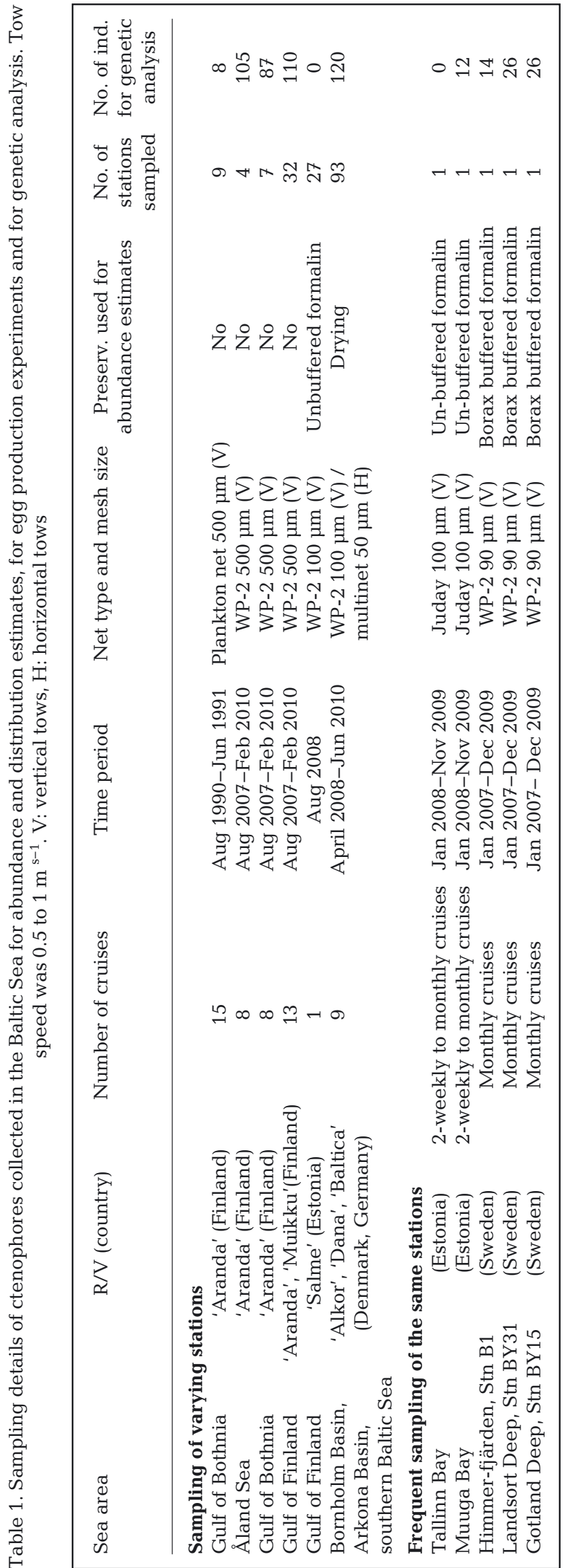

scope with 10 to $60 \times$ magnification within $3 \mathrm{~h}$ of collection. The ctenophores collected within the HELCOM (Baltic Marine Environment Protection Commission) zooplankton monitoring were preserved in formalin and counted under a dissecting microscope within $1 \mathrm{yr}$ of collection. To compare the abundances counted from live versus preserved samples, comparative counts were conducted first from live material and later from the same samples after preservation in $4 \%$ borax buffered formalin and 4 to 5 mo of storage at $4^{\circ} \mathrm{C}$. There was a significant decrease (mean $\pm \mathrm{SD}$ : $14 \pm 1.6 \%$ ) in specimen recovery in the preserved samples (Wilcoxon Signed Rank test; $\mathrm{W}=21.0$, $\mathrm{p}<$ $0.05 ; \mathrm{n}=5$ ). Based on this $14 \%$ loss, we corrected abundance estimates from the preserved samples. The individual size (oral-aboral length, $\mathrm{mm}$ ) of ctenophores was measured from 1487 living individuals under a dissecting microscope either with an ocular scale, millimeter paper or callipers.

The counts per tow were converted to (1) abundances per surface area (ind. $\mathrm{m}^{-2}$ ) to compare the abundances from different samplings (vertically stratified samples and samples from the whole water column) or (2) per volume filtered (ind. $\mathrm{m}^{-3}$ ) to compare abundances from areas with different depths. CTD data of the whole water column were also obtained concurrently with the samplings of the ctenophores. The salinity in the surface and bottom waters between the late 1980s (Vuorinen 1987, Vuorinen \& Vihersaari 1989) and the present data was also compared.

\section{DNA-based identification of specimens}

Genetic analyses of ctenophores collected during the 54 cruises were performed in 2 laboratories. The samples from Swedish, Finnish and Estonian cruises were tested in Stockholm, while analyses for the Danish and German cruises were performed in Kiel. Both laboratories use methods based on the polymorphism in the variable region of the internal transcribed spacer (ITS-region).

Most of the genetic identification assays were done as described by Gorokhova et al. (2009). Ctenophores collected in different sub-basins of the Baltic Sea during 2007-2010 (Table 1) were preserved in 4 different ways: (1) frozen at $-20^{\circ} \mathrm{C},(2)$ dried for $24 \mathrm{~h}$ at $60^{\circ} \mathrm{C}$ and then frozen at $-20^{\circ} \mathrm{C}$, (3) air-dried on filter at ambient temperature and (4) formalin-preserved. DNA was extracted using 10\% Chelex (Aranishi \& Okimoto 2006) and used to amplify $18 \mathrm{~S}$ and ITS1 rDNA with Mertensia-specific primers (see Table 1 in 


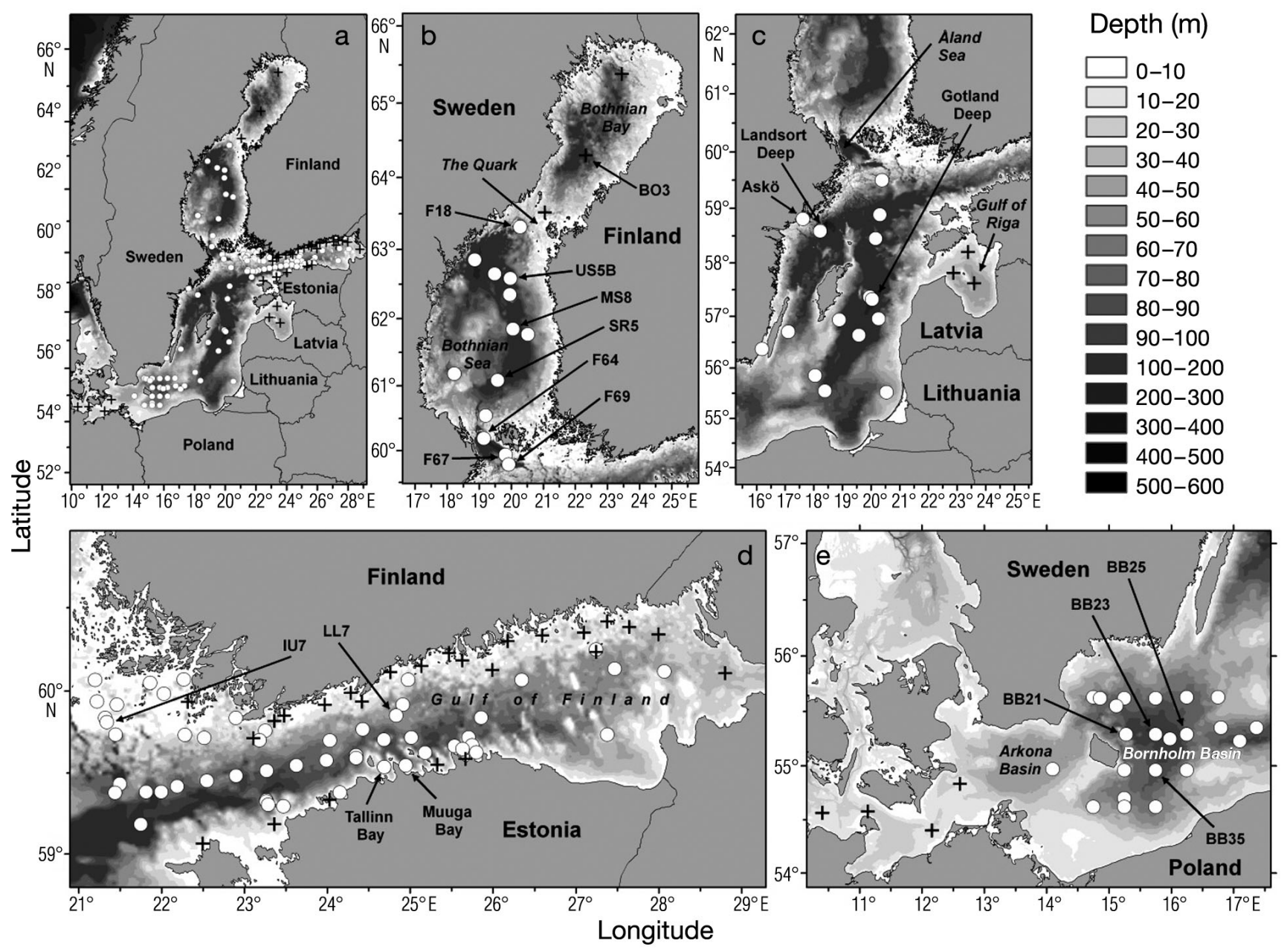

Fig. 1. Stations where Mertensia ovum was observed (circles) or not (+) between 2007 and 2010 in the Baltic Sea. (a) Overview, (b) Gulf of Bothnia (Bothnian Sea, Quark, Bothnian Bay), (c) Central Baltic Proper and Gulf of Riga, (d) Gulf of Finland and (e) Bornholm Basin, Arkona Basin and the Western Baltic Sea. Station names that are mentioned in the text are indicated

Gorokhova et al. 2009). Ten randomly selected PCR products were sequenced using an ABI 3730 PRISM $^{\circledR}$ DNA Analyzer at KIGene (Karolinska Institute, Stockholm) and aligned against Baltic M. ovum (GenBank accession no. FJ668937) to confirm the product identity. Samples that produced no amplification with the species-specific primers were subjected to PCR with universal eukaryotic primers (Kober \& Nichols 2007); none of these samples had DNA amenable to amplification and were therefore classified as failed extractions.

In December 2009, we obtained 8 archival ctenophore individuals (from the collection of P. Välipakka) for DNA analysis. These ctenophores had been collected at Station US5B in the Bothnian Sea on 21 August 1990 onboard R/V 'Aranda' (FIMR) and identified as Pleurobrachia pileus based on their appearance (P. Välipakka unpubl. data). The ctenophores in each sample had been counted, measured (oral-aboral length: $3.8 \pm 1.5 \mathrm{~mm}$, mean $\pm \mathrm{SD}$ ), placed individually on GF/F filters, dried for $24 \mathrm{~h}$ at $60^{\circ} \mathrm{C}$ and stored at $-20^{\circ} \mathrm{C}$ for $19 \mathrm{yr}$ in the Finnish Institute of Marine Research (no longer in existence). These samples were processed as described above for the recently collected samples; however, for each individual, 3 PCRs were run using both Mertensiaand Pleurobrachia-specific primers as well as universal primers, as described in Gorokhova et al. (2009). The PCR products were sequenced as described above and the unique sequence was deposited in GenBank (accession no. JQ622252).

Ctenophores collected on the research vessels 'Alkor' and 'Dana' were genetically identified as described in Jaspers et al. (2012). Specimens were preserved individually by drying on filter paper onboard, cut out and lysated in $30 \mu \mathrm{l}$ Tris-EDTA, 1X Solution ( $\mathrm{pH} 7.6$; Fisher BioReagents) at $52^{\circ} \mathrm{C}$ for $30 \mathrm{~min}$. The species identification was done by dia- 
gnostic PCR with specific primers (see supporting online material 1a in Jaspers et al. 2012). Diagnostic PCR was conducted using the Phire Hot Start DNA Polymerase (Finzymes). The PCR-Mix (total volume: $10 \mu \mathrm{l})$ contained $2 \mu \mathrm{l} 5 \mathrm{X}$ Phire reaction buffer, $0.2 \mu \mathrm{l}$ dNTPs, $1 \mu \mathrm{l}$ forward primer, $1 \mu \mathrm{l}$ reverse primer, $0.2 \mu \mathrm{l}$ Phire Polymerase, $4.6 \mu \mathrm{l}$ HPLC- $\mathrm{H}_{2} \mathrm{O}$ and $1 \mu \mathrm{l}$ template. PCR cycles consisted of denaturation and enzyme activation at $98^{\circ} \mathrm{C}(5 \mathrm{~min})$ followed by 33 cycles of denaturation, annealing and elongation at $98^{\circ} \mathrm{C}(8 \mathrm{~s}), 58.5^{\circ} \mathrm{C}(15 \mathrm{~s})$ and $72^{\circ} \mathrm{C}(15 \mathrm{~s})$, respectively, and final extension at $72^{\circ} \mathrm{C}(2 \mathrm{~min})$. PCR products were visualised on $1.5 \%$ agarose gel stained with ethidium bromide.

\section{Egg production}

Mertensia ovum eggs were collected during a research cruise on R/V 'Aranda' in September 2007 at stations IU7 and F69 near Åland Island (Fig. 1b,d). The eggs were sampled with a closing WP-2 net (100 $\mu \mathrm{m}$ mesh) in 10 depth layers (9 vertical tows in $15 \mathrm{~m}$ depth steps from the bottom [185 $\mathrm{m}$ depth] to $50 \mathrm{~m}$ depth, and 1 tow from $50 \mathrm{~m}$ depth to the surface) to determine their vertical distribution in the water column. Using a dissecting microscope, the eggs were counted within $2 \mathrm{~h}$ of collection.

In September 2008, egg production experiments were conducted on a research cruise on R/V 'Aranda' at stations F64 and F67 in the Åland Sea (Fig. 1b). Actively swimming, undamaged Mertensia ovum (n $=56$; size range: 2 to $6.5 \mathrm{~mm}$, mean $\pm \mathrm{SD}: 4.1 \pm$ $0.3 \mathrm{~mm}$ ) were carefully picked with a table spoon from a large container immediately after towing (WP-2 net with a cod end, $500 \mu \mathrm{m}$ mesh) and placed individually in plastic vials containing $50 \mathrm{ml}$ of $0.2 \mu \mathrm{m}$ filtered seawater. The incubations lasted $24 \mathrm{~h}$ at in situ temperature $\left(\sim 4^{\circ} \mathrm{C}\right)$ and salinity $(6.5)$ in darkness. After $24 \mathrm{~h}$, the ctenophore oral-aboral length was measured, and the number of eggs was counted to determine egg production rate (EPR, eggs ind.$\left.^{-1} \mathrm{~d}^{-1}\right)$. Also, size-specific EPR was calculated by dividing the individual EPR by the oral-aboral length of the ctenophore (eggs $\mathrm{mm}^{-1} \mathrm{~d}^{-1}$ ).

\section{Statistical analysis}

To evaluate the distribution of Mertensia ovum as a function of environmental factors, a Hurdle regression model was applied, given that the ctenophore abundances were zero-inflated and over-dispersed
(Potts \& Elith 2006). The Hurdle regression model is a 2-component model with a component that models the zero counts (the presence-absence model component) and a truncated count component for positive counts (the count model component). To build this model, a binomial probability model and a truncatedat-zero count data model were fitted separately (Welsh et al. 1996). The presence-absence model or the probability of finding zero or positive abundance values were adjusted to a binomial distribution with a logit link, whereas the count model was fitted to a truncated at zero log-normal distribution using the generalized linear regression module in S-PLUS 8.0 for Windows. We chose 6 environmental variables for consideration in the models based on availability and known or plausible roles in influencing plankton distributions in the Baltic Sea: temperature $\left({ }^{\circ} \mathrm{C}\right)$, salinity, oxygen $\left(\mathrm{ml} \mathrm{l}^{-1}\right)$, bottom depth at the sampling station (m) as continuous variables, and season (summer: June to October or winter: December to April, defined according to Bradtke et al. 2010) and geographic area (Bothnian Sea, Åland Sea, Gulf of Finland, Central Baltic Proper, Bornholm Basin; Fig. 1) as categorical predictors. To improve distributions of the model residuals, the temperature and salinity values were subjected to a Box-Cox transformation. Pearson correlation analysis was used to identify significant correlation among the continuous explanatory variables. The Akaike Information Criterion (AIC) was used to identify the best model (best subset regression) and to optimize the number and combination of predictive variables included. When validating the proposed models, the Wald statistic was used to check the significance of the regression coefficient for each parameter. A likelihood ratio test was then used to evaluate the statistical significance of including or not including each parameter, and model goodness of fit was checked using deviance and Pearson $\chi^{2}$ statistics. The change in deviance for single variables was used to estimate the contribution of individual variables to the deviance explained by the final model (Collet 1991). Residual plots for each model were examined to exclude remaining unattributed structure indicative of a poor model fit.

We used a non-parametric Mann-Whitney U-test to analyse the differences between summer and winter ctenophore abundances in the Bornholm Basin and the Bothnian Sea. To evaluate the difference between individual sizes of ctenophores found in different basins of the Baltic Sea a non-parametric KruskalWallis test was applied. The correlation between the length of the spawned individuals and egg production rate was tested with the Spearman correlation. 
Non-parametric tests were chosen due to non-normal distributions and/or heterogeneous variances in the compared data sets.

To test the difference in salinity between the 2 sampling periods of ctenophores (late 1980s and late 2000s) in surface and bottom water, a non-parametric Wilcoxon Signed Rank test was used. The mean salinity in the uppermost meter of the water column was defined as surface salinity, whereas the mean salinity from 1 to $2 \mathrm{~m}$ above the bottom was defined as bottom salinity. Historical data were taken from Vuorinen (1987) and present day data came from CTD data obtained concurrently with the samplings of ctenophores at the same stations as those sampled by Vuorinen (1987). The tests were done using SPSS v.20.

\section{RESULTS}

\section{DNA-based identification}

Of the 388 ctenophores collected in the northern Baltic proper and adjacent bays (Table 1), 18 specimens $(5 \%)$ did not produce any amplification with either Mertensia-specific or universal primers, while the remaining 370 specimens (95\%) were all identified as Mertensia ovum. Most of the specimens not amenable for amplification originated from the formalin-preserved samples collected from stations Landsort Deep and Gotland Deep (Fig. 1c). There was no variation among the 10 randomly selected PCR products that were sequenced, and they were identical to $M$. ovum from the Baltic Sea (GenBank accession no. FJ668937; Gorokhova et al. 2009). Among the 120 ctenophore individuals collected in the Southern and Central Baltic (Bornholm Basin on 'Alkor' and 'Dana' cruises), 110 individuals (92\%) were identified as $M$. ovum, 3 individuals (2\%) were $M$. leidyi, and the remaining 7 individuals (6\%) produced no amplification. Thus, the populations studied in 2007-2010 consisted almost exclusively of a single species, Mertensia ovum.

\section{Distribution and abundance}

The arctic ctenophore Mertensia ovum was found in all basins of the Baltic Sea (Fig. 1a), except the northernmost Bothnian Bay (Fig. 1b), the Gulf of Riga (Fig. 1c), coastal areas of the Gulf of Finland (Fig. 1d) and the western Baltic Sea (Fig. 1e). The highest densities of ctenophores were found in the open sea areas of the Bornholm Basin (up to 68 ind. $\mathrm{m}^{-3}$;
Fig. 2d), the Aland Sea (39 ind. $\mathrm{m}^{-3}$; data not shown) and the Gulf of Finland (up to 41 ind. $\mathrm{m}^{-3}$; Fig. 2a,e and 31 ind. $\mathrm{m}^{-3}$; Fig. 2e). Maximum abundances were 11 to 13 times lower in coastal areas (Swedish coast: 6 ind. $\mathrm{m}^{-3}$, Fig. 2f; Finnish coast: 3 ind. $\mathrm{m}^{-3}$, data not shown) as well as in the deepest parts of the central Baltic Proper (Gotland Deep: 5 ind. $\mathrm{m}^{-3}$; Landsort Deep: 3 ind. $\mathrm{m}^{-3}$; Fig. 2b,c respectively). Overall, abundances were highest from late autumn to early spring, decreasing to very low numbers in summer (Fig. 2). The difference between summer and winter abundances was significant only in the Landsort Deep (Fig. 2c) (Mann-Whitney $U$-test: $z=$ $-2.56, \mathrm{p}=0.009$ ).

The vertical distribution of Mertensia ovum changed with season, and maximum abundances were generally found in the coldest parts of the water column (Fig. 3). During summer, most of the populations were found in deeper water layers (Fig. 3a,b). During winter and spring, the distribution varied by region. In the Bothnian Sea, the distribution seemed to be more even in wintertime compared to summer, although the poor sampling resolution did not allow for the testing this trend (Fig. 3c). In the Bornholm Basin, M. ovum was also found in the surface layer in spring, although its population maximum was at 10 to $20 \mathrm{~m}$ (Fig. 3d). A small part of the population $(<3 \%)$ was found in deep layers below the halocline also during winter months.

Mertensia ovum was found in a wide range of abiotic conditions in the Baltic Sea, covering salinities between 5.5 and 16 , temperatures from 1 to $8.5^{\circ} \mathrm{C}$, and a broad range of oxygen conditions (down to $1 \mathrm{ml} \mathrm{l}^{-1}$ ) (Fig. 3). Highest ctenophore abundances were found at salinities $\geq 5.5$, temperatures $<7^{\circ} \mathrm{C}$, and oxygen concentrations $>4 \mathrm{ml} \mathrm{l}^{-1}$. There was a strong negative correlation between salinity and oxygen (Table 2), resulting from overlapping low salinity and well oxygenated waters in the Bothnian Sea. Moderate correlations occurred between temperature and oxygen and between salinity and bottom depth (Table 2). Although these correlations among the explanatory variables were statistically significant, even the most strongly correlated variables (salinity and oxygen) do not overlap entirely as there is a strong horizontal gradient in salinity from 4.9 in the Bothnian Sea to 15.9 in the Bornholm Basin, in addition to the vertical salinity gradient, with increasing salinities from surface to bottom. Therefore, collinearity among the explanatory variables was not deemed sufficient to drop variables from the full models, but was considered in the interpretation of model selection results. 

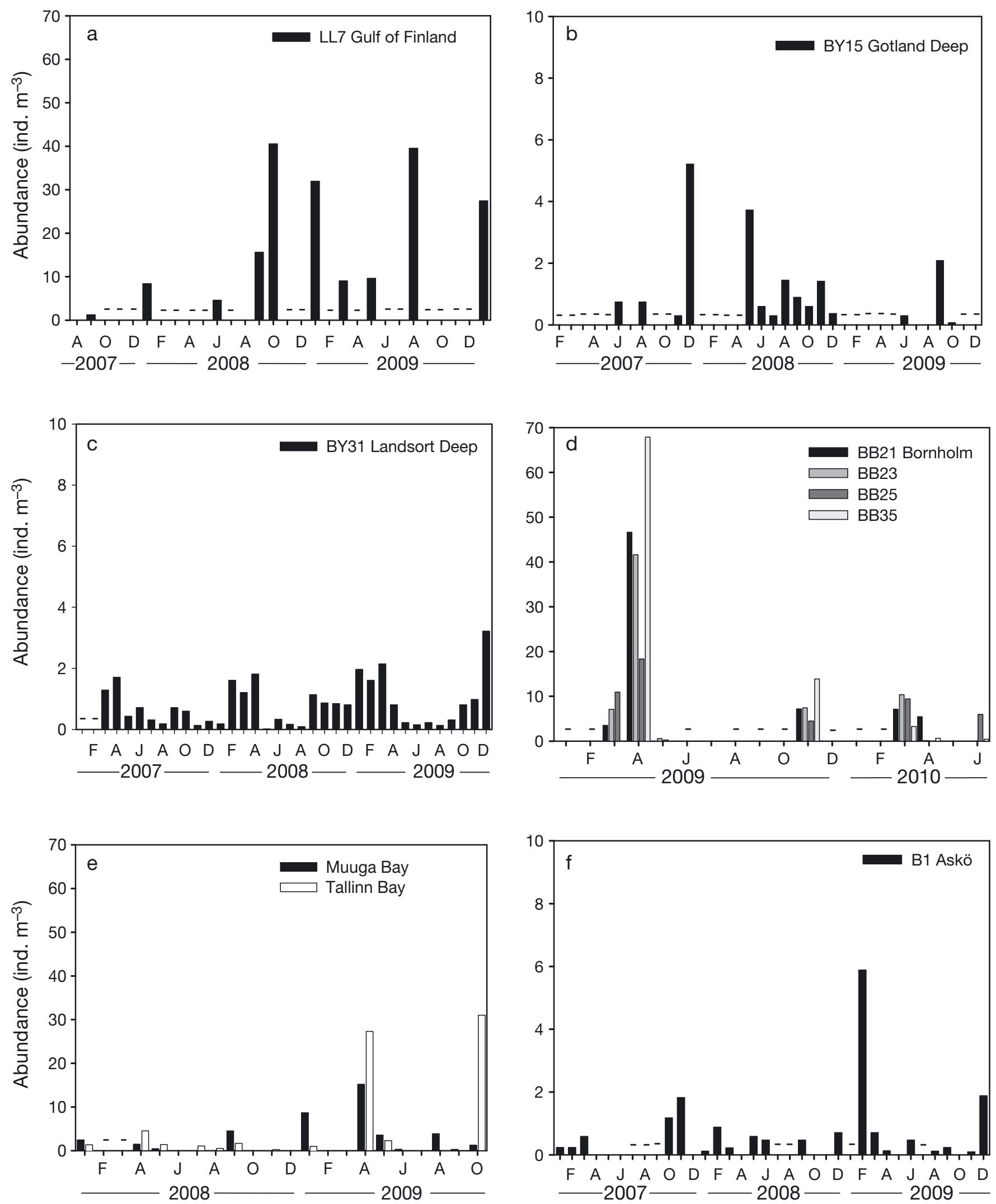

Fig. 2. Mertensia ovum. Seasonal population dynamics of ctenophores at 7 open sea sampling stations (a-d) and 3 coastal stations (e,f) representing 3 sub-basins of the Baltic Sea (Gulf of Finland, Baltic Proper and Bornholm Basin). (-) no data 

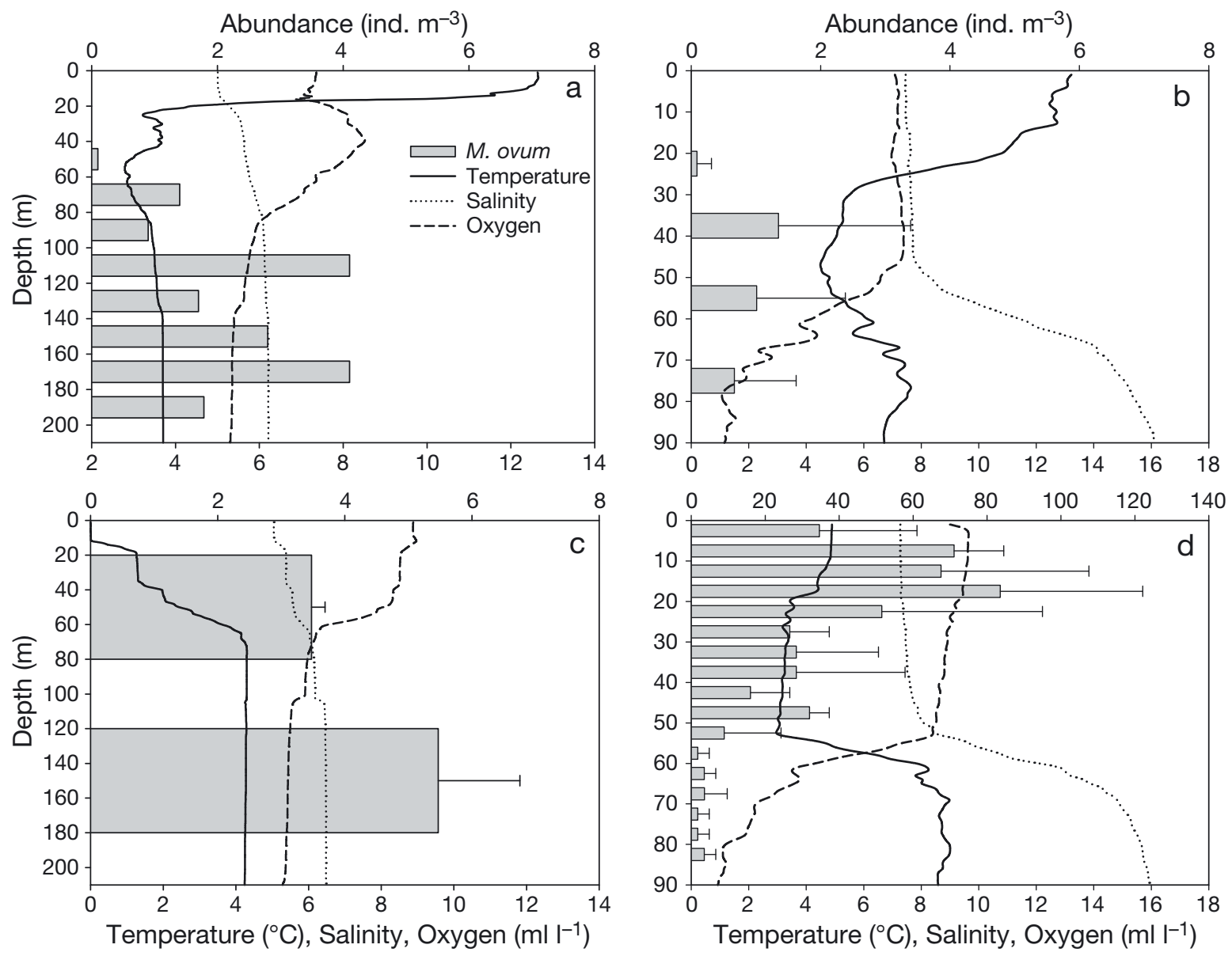

Fig. 3. Mertensia ovum. Vertical profiles of hydrographic factors (salinity, temperature and oxygen) and ctenophore abundances at a northern Baltic Sea station (Bothnian Sea, US5B) in (a) summer (10 Sep 2008, n= 1 tow) and (c) winter (20 Jan 2010 , $\mathrm{n}=3$ tows), and at a southern Baltic Sea station (Bornholm Basin, BB23) in (b) summer (4 June 2008, $\mathrm{n}=18$ tows) and (d) spring

(12 April 2009, $\mathrm{n}=3$ tows). Note different depth scales between stations. In (b-d): bars = means, whiskers $=\mathrm{SD}$

The presence-absence model indicated that the probability of ctenophore occurrence increases with decreasing temperature and bottom depth (Table 3). Bottom depth was again a negative predictor in the count part of the hurdle models that also indicated a positive relationship between ctenophore abundance and dissolved oxygen, and a significant seasonal

Table 2. Pearson correlation coefficients between the continuous environmental variables. Temperature, salinity and oxygen were measured during all seasons from 2007 to 2010 on the research cruises in the Baltic sea. Bold: significant correlations $(\mathrm{p}<0.05) ; \mathrm{n}=102$

\begin{tabular}{|lccc|}
\hline & Temperature & Salinity & Oxygen \\
\hline Salinity & 0.08 & & \\
Oxygen & $\mathbf{- 0 . 3 6}$ & $\mathbf{- 0 . 7 2}$ & \\
Bottom depth & -0.08 & $\mathbf{- 0 . 3 5}$ & 0.040 \\
\hline
\end{tabular}

component, with higher abundances observed in winter than in summer (Table 3). The latter is consistent with the temperature effect observed in the presence-absence model.

Table 3. Hurdle model selection results for ctenophore presence-absence and abundance in the Baltic Sea. Significance test $\mathrm{p}$-values are given for the explanatory variables temperature, bottom depth, oxygen concentration, and season

(winter vs. summer). Bold: significant effects $(p<0.05)$

\begin{tabular}{|lrrr|}
\hline Effect & Estimate & $\begin{array}{c}\text { Wald } \\
\text { statistic }\end{array}$ & $\mathrm{p}$ \\
\hline Presence-absence model & & & \\
Temperature & -1.201 & 19.75 & $<\mathbf{0 . 0 0 1}$ \\
Bottom depth & -0.002 & 2.68 & 0.102 \\
Count model & & & \\
Oxygen & 1.316 & 11.68 & $<\mathbf{0 . 0 0 1}$ \\
Bottom depth & -0.003 & 9.36 & $\mathbf{0 . 0 0 2}$ \\
Season & 0.187 & 8.34 & $\mathbf{0 . 0 0 4}$ \\
\hline
\end{tabular}




\section{Size and egg production}

Mertensia ovum individuals were on average larger in the northernmost areas of occurrence, the Bothnian Sea (mean \pm SD: $2.33 \pm 1.2 \mathrm{~mm}_{\text {; }}$ range: 0.3 to $6.5 \mathrm{~mm}$ ) compared to the Gulf of Finland $(0.9 \pm$ $0.4 \mathrm{~mm}_{i} 0.3$ to $\left.3.5 \mathrm{~mm}\right)$ and the Bornholm Basin $(0.7 \pm$ $0.6 \mathrm{~mm} 0.2$ to $8.3 \mathrm{~mm}$ ). Size differences between the areas were significant (Kruskal-Wallis test: $H=$ 762.5, df $=2, \mathrm{p}<0.001$ ).

Although the ctenophore size never exceeded $9 \mathrm{~mm}$, egg production was observed in both the plankton samples (Bornholm Basin, Gulf of Finland, Åland Sea and Bothnian Sea) and the laboratory incubations. Eggs were not included in the routine abundance analysis of the ctenophores (they were only noted as absent or present), thus in situ abundances are only available for a few stations. At stations IU7 and F69, near the Åland Island, egg numbers varied between 356 and $1376 \mathrm{~m}^{-2}$. Eggs were found in all water layers below the thermocline, with the highest concentrations from 50 to $80 \mathrm{~m}$ depth (Fig. 4a) and maxima of 90 eggs $\mathrm{m}^{-3}$ between 60 and $70 \mathrm{~m}$ depth at station IU7 and 9 eggs $\mathrm{m}^{-3}$ between 65 and $80 \mathrm{~m}$ depth at station F69.

In the experiments using field-collected Mertensia ovum, EPR was $2.2 \pm 1.0$ eggs ind. ${ }^{-1} \mathrm{~d}^{-1}$ (range: 0 to 22 eggs ind. ${ }^{-1} \mathrm{~d}^{-1}$ ). No egg production was observed in individuals $<3.5 \mathrm{~mm}$ (Fig. $4 \mathrm{~b}$ ), whereas the percentage of spawning individuals among those $>3.5 \mathrm{~mm}$ was $72 \%$. There was no correlation between egg production rate and length of the spawned ctenophores (Spearman correlation $\mathrm{p}>0.05$ ). The size specific EPR was $1.0 \pm 0.9$ eggs $\mathrm{mm}^{-1} \mathrm{~d}^{-1}$.

Based on the measured EPR for individuals of different sizes, possible EPR for a natural population of Mertensia ovum in the Åland Sea was calculated. By assuming that only $72 \%$ of individuals $(>3.5 \mathrm{~mm}$ ) produced eggs, the spawning population was estimated to be only $20 \%$ of the entire natural population. A population of 620 ind. $\mathrm{m}^{-2}\left(\sim 3.5\right.$ ind. $\left.\mathrm{m}^{-3}\right)$ could therefore theoretically produce ca. 400 eggs $\mathrm{m}^{-2}$ $\mathrm{d}^{-1}\left(\sim 2.1\right.$ eggs $\left.\mathrm{m}^{-3}\right)$. This is very close to the observed egg abundance in the same area $\left(\sim 2.6\right.$ eggs $\mathrm{m}^{-3}$

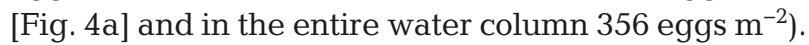

\section{Re-identification of archival individuals}

Seven out of 8 ctenophore individuals collected in 1990 were successfully amplified using Mertensiaspecific primers, and none produced positive amplifications with Pleurobrachia-specific primers. The
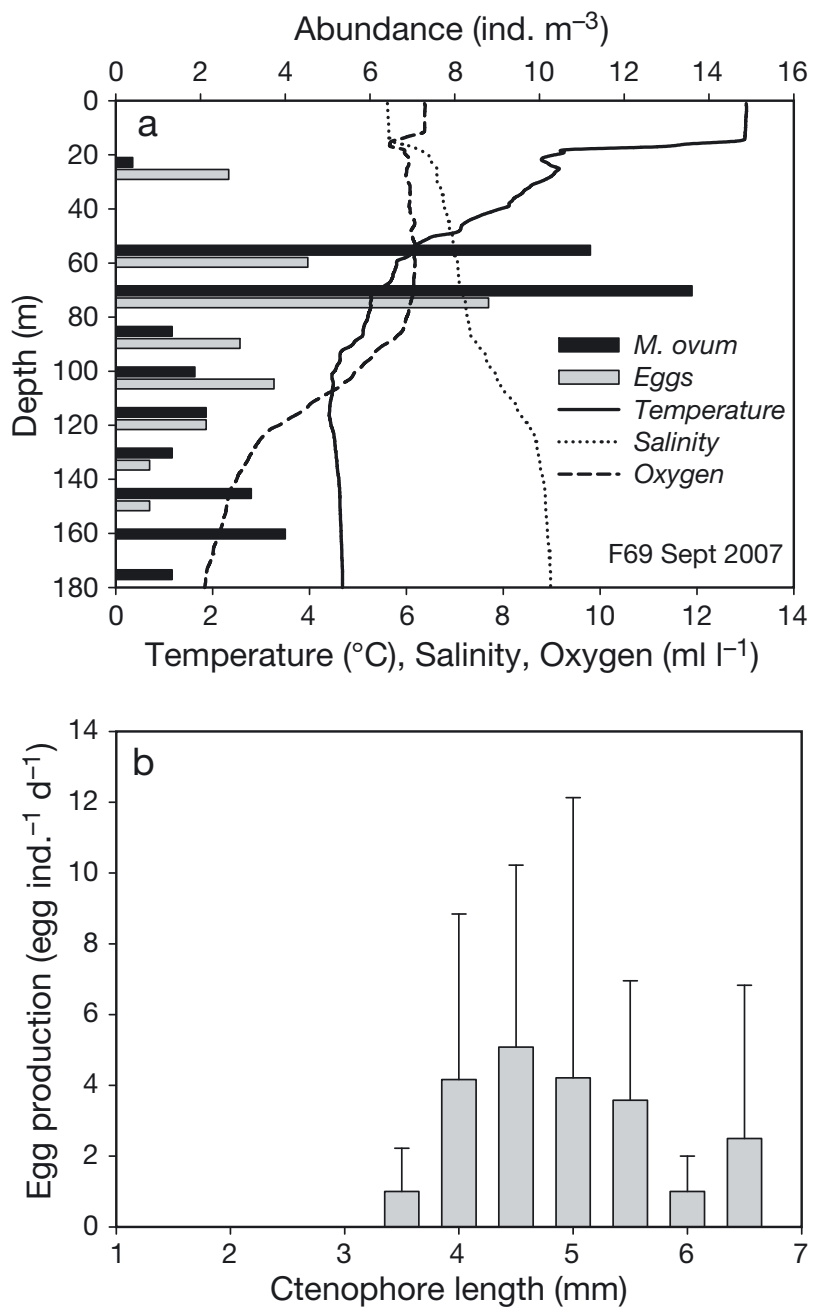

Fig. 4. Mertensia ovum. (a) Vertical profile of individual and egg abundances, and hydrographic factors (salinity, temperature and oxygen) at Station F69 in the Åland Sea in September 2007. (b) Egg production as a function of ctenophore size in $24 \mathrm{~h}$ incubations ( $\mathrm{n}=3$ to 9 per size). In (b): bars = means, whiskers $=\mathrm{SD}$

sequenced fragment $(294 \mathrm{bp}$; GenBank accession no. JQ622252) was $100 \%$ identical to the corresponding part in the FJ668937 sequence, not taking into account ambiguous codons. DNA extraction failed in 1 sample. We concluded that all archival individuals were of the single species Mertensia ovum.

\section{Comparison between abundances and salinities over $20 \mathrm{yr}$}

Mertensia ovum abundances from 2007 to 2009 were compared to those determined in the early 1990s (Station SR5, the Bothnian Sea) based on the assumption that all Pleurobrachia pileus (P. Välipakka 

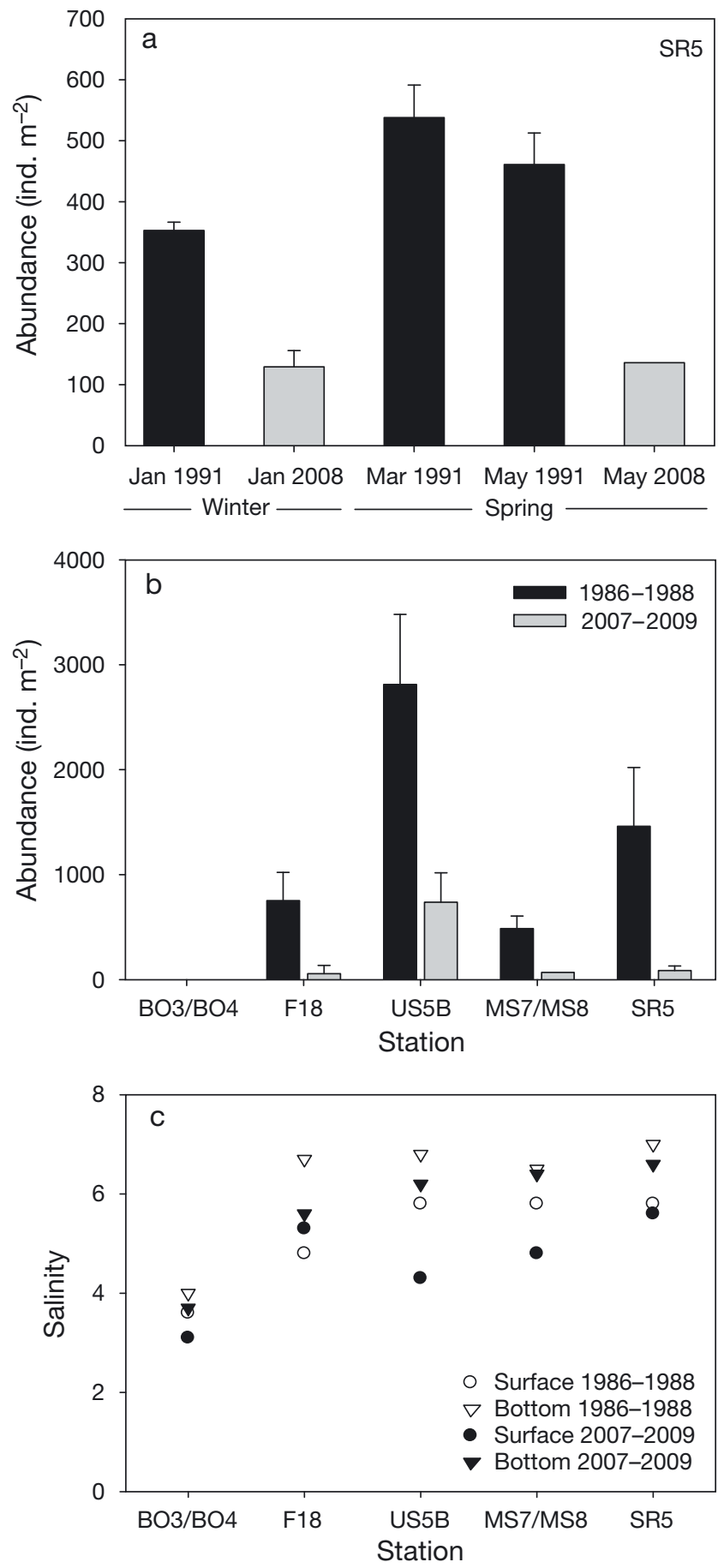

Fig. 5. Mertensia ovum. (a) Winter and spring ctenophore abundances in 1991 (black bars) and 2008 (grey bars) at Station SR5 in the Bothnian Sea, northern Baltic Sea (3 tows per sampling). (b) Abundances at several stations (3 tows per sampling) in the Gulf of Bothnia, northern Baltic Sea in August-September of 1986 and 1988 (data from Vuorinen 1987 and Vuorinen \& Vihersaari 1989, respectively) and $2007-$ 2009. (c) Average salinities in surface and bottom waters at the Bothnian Sea stations, where ctenophores were sampled in 1986-1988 and 2008-2009 (shown in b). Data sources as for $(b)$. In $(a, b)$ : bars = means, whiskers $=S D$ unpubl. data) were actually $M$. ovum. Ctenophore abundances observed in 2008 were $35 \%$ of those observed in 1991 for January, and only $30 \%$ of the abundances in 1991 for May (Fig. 5a). Present summer abundances were 10 to $30 \%$ of the abundances observed in the late 1980s throughout the Bothnian Sea (Vuorinen 1987, Vuorinen \& Vihersaari 1989; Fig. 5b). The observed length (oral-aboral) ranges were similar between time periods: during several cruises in 1991, the ctenophore size varied from 0.3 to $11 \mathrm{~mm}$ (data not shown) corresponding well with the present day range from 0.3 to $8.5 \mathrm{~mm}$.

In the Bothnian Sea salinity was 0.5 to 1 higher in the late 1980s than in the late 2000s (Fig. 5c). The difference in salinity between the 2 periods was significant for bottom waters (Wilcoxon signed rank test: $\mathrm{p}=0.027)$ but not for surface waters $(\mathrm{p}=0.141)$.

\section{DISCUSSION}

Based on our results, the arctic ctenophore Mertensia ovum occurs in almost the entire Baltic Sea. The northern limit of distribution is the Bothnian Bay, maybe due to the low salinity in this area. It remains unexplained why the species was also not found in the westernmost areas near the Kattegat and Danish Straits, where salinity is closer to salinities of the North Sea. The first report of $M$. ovum occurrence in the Baltic was based on samples collected in 2008 (Gorokhova et al. 2009). Otherwise, the species is known only from the Arctic Seas (Graeve et al. 2008) where its population peaks during summer, likely due to the high concentration of zooplankton prey (Lundberg et al. 2006). Since the diet of M. ovum in the Baltic is not known, we cannot speculate on how much the abundance and vertical distribution of prey affect its occurrence and distribution. Our study shows that the population dynamics of $M$. ovum in the Baltic Sea (with highest abundances occurring from late autumn to spring) are different from those in the Arctic. The vertical distribution of $M$. ovum is also very different between the areas. In the Arctic, this ctenophore occurs in the mixed surface layer, mainly between $25 \mathrm{~m}$ and the surface (in situ observations; Raskoff et al. 2005, Purcell et al. 2010), while in the Baltic, we found the highest concentrations in deeper waters, near and below the halocline. These differences are most probably related to prevailing physical conditions. M. ovum is a marine, cold water species (e.g. Blachowiak-Samolyk et al. 2008), which probably lives on the edge of its physiological tolerance in the brackish Baltic Sea. Based on our results, 
the species prefers the water layers with higher salinity $(>5.5)$ and low temperature $\left(<7^{\circ} \mathrm{C}\right)$, which would include the deep waters below the halocline during summer but also surface waters during winter in areas where salinity is relatively high, such as in the southern Baltic. Depth in addition to oxygen and temperature regulates the abundance of $M$. ovum in the Baltic Sea. It prefers areas with depth $>70 \mathrm{~m}$, as all the high abundances were observed in the deeper and well oxygenated areas. Low abundances were found in both coastal and open sea areas where oxygen was depleted. Low abundances in the deeper parts of the central Baltic Proper are probably due to permanent bottom anoxia and deep-water layers suffering from oxygen deficiency (Laine et al. 1997). In coastal areas, lower abundances may be due to warmer water temperatures (during summer), freezing of the water column (during winter) and lower salinity due to riverine freshwater input.

The abundances of Mertensia ovum are much higher in the Baltic Sea (max. 68 ind. $\mathrm{m}^{-3}$ in the south and 40 ind. $\mathrm{m}^{-3}$ in the north) compared with the reported abundances from the Arctic (maximum abundances of 1 to 12 ind. $\mathrm{m}^{-3}$ in Resolute Passage [Siferd \& Conover 1992] and 4.7 ind. $\mathrm{m}^{-3}$ in Svalbard waters [Lundberg et al. 2006]). These abundances are probably underestimates, because ctenophore larvae are often counted as an unidentified group due to identification problems based on morphological characters (e.g. Purcell et al. 2010), and thus left out of the $M$. ovum counts. Furthermore, small $(<0.5 \mathrm{~mm})$ specimens were probably not captured by the relatively coarse nets used $(1000 \mu \mathrm{m}$ mesh size; e.g. Lundberg et al. 2006). Future studies in the Arctic should estimate the importance of the small-sized ctenophores as well as genetically validate the species in order to fully understand the community dynamics of ctenophores and their biodiversity. In other marine areas worldwide, abundances of some ctenophore species are regulated by other ctenophore species (Vinogradov et al. 2000, Purcell et al. 2001). This may be the case in the western Baltic Sea as well, where Mnemiopsis leidyi (Javidpour et al. 2009) or Beroe spp. are present but not in the central and northern parts, where these 2 predatory ctenophores are absent. However, the importance of other predators, such as mysids and fish, is unclear.

Individuals of Mertensia ovum in the Baltic Sea are relatively small compared to the Arctic ones. The average size of all specimens we collected from different sub-basins was $1.4 \mathrm{~mm}$ (largest observed individual $8.3 \mathrm{~mm}$ ), thus smaller size classes dominate the population. In the Arctic, the average size is
$15.9 \mathrm{~mm}$ (Swanberg \& Båmstedt 1991). The largest individuals are found from July to September, while smaller individuals $(<5 \mathrm{~mm})$ are observed throughout the year in the Arctic (Siferd \& Conover 1992). The smaller size of $M$. ovum in the Baltic is probably an adaptation to low salinity, a phenomenon which has been documented for many other marine species occurring also in brackish waters e.g. herring (Remane \& Schlieper 1971). Also animals (including ctenophores) living in polar regions grow larger compared to their conspecifics in warmer and more shallow waters (e.g. see Moran \& Woods 2012 for review). These differences in ctenophore body size, between the polar and temperate regions, will likewise have an influence on other life history traits, such as egg size, size at first reproduction, and metabolic rates.

The production of eggs by Mertensia ovum was observed both in the laboratory and in the field throughout the Baltic. Eggs were present all year round indicating a continuous reproduction, which was also suggested by Jaspers et al. (2012) for $M$. ovum in the central Baltic. In the Arctic, a prolonged reproduction has been observed from May to August (e.g. Siferd \& Conover 1992), with a peak in late summer as indicated by a large number of small specimens (Lundberg et al. 2006). Continuous reproduction in the Baltic Sea may compensate for a low average reproduction rate $\left(\sim 2\right.$ eggs ind.$\left.^{-1} \mathrm{~d}^{-1}\right)$. This seems to be the case for the Bothnian Sea, Alland Sea and Baltic Proper, where we observed potentially reproductive individuals ( $>3.5 \mathrm{~mm}$ ) year-round. However, in the Gulf of Finland, large individuals were rarely observed in the samples and only during winter. This also seems to be the case in the central Baltic Sea where Jaspers et al. (2012) only reported small sized ctenophores. It appears, therefore, that Baltic M. ovum becomes reproductive at a small size. It is unclear if this represents a phenomenon known in ctenophores as paedogenesis, i.e. larval reproduction (Martindale 1987), or if the individuals that were found reproductively active are in fact fully functional adults. To firmly establish population-specific reproduction capabilities of this species, a comparative study using Arctic and Baltic populations is needed, including characterization of larval and adult gonad development.

The EPR observed in our study are similar or slightly lower when compared to those in similarlysized ctenophores and very low when compared to those in larger (24 to $30 \mathrm{~mm}$ ) ctenophores, such as adult Mnemiopsis leidyi (1000 to 14000 eggs ind. ${ }^{-1}$ $\mathrm{d}^{-1}$; Baker \& Reeve 1974, Kremer 1976, Purcell et al. 2001 review; our Table 4). The size-specific EPR also 
Table 4. Mertensia ovum, Pleurobrachia bachei, Mnemiopsis leidyi and Mnemiopsis mccradyi average egg production rates and details of incubation experiments.

\begin{tabular}{|lcccl}
\hline Ctenophore species (area) & $\begin{array}{c}\text { Mean egg prod. } \\
\text { (eggs ind }{ }^{-1} \mathrm{~d}^{-1} \text { ) }\end{array}$ & $\begin{array}{c}\text { Ctenophore size } \\
\text { range }(\mathrm{mm})\end{array}$ & $\begin{array}{c}\text { Methods (size of jar, } \\
\text { temperature, duration) }\end{array}$ & Source \\
\hline M. ovum (Baltic) & 3 & $3.5-6.5$ & $50 \mathrm{ml}, 4^{\circ} \mathrm{C}, 1-3 \mathrm{~d}$ & This study \\
& $<1$ & $0.8-1.3$ & $20 \mathrm{ml}, 7 \pm 11^{\circ} \mathrm{C}, 1 \mathrm{~d}$ & Jaspers et al. (2012) \\
P. bachei (Pacific, Canada) & 2 & 6 & $71(10 \mathrm{ind}), 13^{\circ} \mathrm{C}, 6 \mathrm{~d}$ & Reeve et al. (1978) \\
M. leidyi (Caspian Sea) & 905 & $12-42$ & $2 \mathrm{l}, 22-25^{\circ} \mathrm{C}, 2 \mathrm{~d}$ & Finenko et al. (2006) \\
M. mccradyi (Atlantic, USA) & 8 & $1.8-2.5$ & $<300 \mathrm{ml}, 22 \pm 1^{\circ} \mathrm{C}, 7 \mathrm{~d}$ & Martindale (1987) \\
& 2130 & $29-81$ & $21,21-31^{\circ} \mathrm{C}, 1 \mathrm{~d}$ & Baker \& Reeve (1974) \\
\hline
\end{tabular}

reveals the lower reproduction potential of the Baltic Mertensia ovum populations compared with M. lei$d y i$ in the coastal USA and in the Caspian Sea $(M$. ovum ca. 1 egg mm $\mathrm{mm}^{-1}$ vs. M. leidyi ca. 30 eggs $\mathrm{mm}^{-1}$; Baker \& Reeve 1974, Finenko et al. 2006). This may be caused by the low temperatures of the Baltic Sea. There are no published studies on $M$. ovum egg production from the Arctic, so intraspecific comparison between seas is not possible.

\section{Potential misidentification of historical samples}

During the last $100 \mathrm{yr}$, Pleurobrachia pileus was the only ctenophore species reported to occur in the central and northern Baltic Sea, north of the Bornholm Basin (e.g. Ackefors 1969, Vuorinen 1987, Vuorinen \& Vihersaari 1989), and one of several ctenophore species reported in the southern and western parts of the sea (Mielck 1926, Ackefors 1969, Schneider 1987). Our identification of the arctic ctenophore Mertensia ovum in the northern Baltic shows the importance of genetic methods for species identification in ctenophore research (see also Gorokhova et al. 2009). The PCR-based analysis of 20 yr old ctenophore samples suggests the possibility that $M$. ovum has been misidentified as $P$. pileus in earlier studies conducted in the central and northern Baltic Sea. Further evidence for this possibility is the clear similarity in present and historical ctenophore distributions as well as in the vertical abundance patterns, with higher abundances in deeper water layers (Mielck 1926, Mielck \& Künne 1935, Ackefors 1969, Vuorinen 1987). Earlier reports also describe the Baltic 'P. pileus' as easily breaking, very fragile and small in size when compared with the North Sea $P$. pileus (Mielck 1926, Mielck \& Künne 1935), which corresponds well with our experience in working with $M$. ovum. Additionally, while $P$. pileus has been found in brackish waters in Chesapeake Bay (Grant \& Olney 1979), there are no reports from salinities as low as those observed in our study in the northern or central parts of the Baltic Sea. This may indicate that $M$. ovum tolerates lower salinities than $P$. pileus and that $P$. pileus likely could not have been common in the northern parts of the sea earlier either. Our analyses are based on a limited dataset ( 7 specimens) thus it is possible that some $P$. pileus have occurred in more saline parts of the Baltic Sea in the past. However, regarding the present-day ctenophore assemblage in the Baltic Sea, P. pileus seems to be absent, as it is not likely that this species was simply missed in our investigation, given the large number of ctenophores analysed, both microscopically and genetically.

\section{Change in ctenophore abundances over time}

Assuming that Pleurobrachia pileus abundances in the Baltic Sea in the late 1980s and early 1990s actually referred to Mertensia ovum, present-day M. ovum abundances in the northern areas are clearly lower ( 70 to $94 \%$ lower), while they are higher (up to $80 \%$ ) in the southern Bornholm Basin. This difference in abundances between time periods can be partially explained by the very patchy distribution of $M$. ovum (indicated by the high variation between replicate tows; Vuorinen 1987, our Fig. 3b-d). Our genetic analyses revealed that larval $M$. leidyi were also present in the Bornholm Basin from spring to autumn ( $2 \%$ of the cydippid specimens). Due to low salinity, the reproduction of Mnemiopsis leidyi is low in this area (Lehtiniemi et al. 2012); thus, the vast majority of the cydippid ctenophores in the Bornholm Basin were likely $M$. ovum. Under these conditions, larval M. leidyi could only have occurred in very small numbers recently, which would not explain the large increase in ctenophore abundance over $20 \mathrm{yr}$ in this area. The observed decrease in $M$. ovum abundances in the northern basin over the past 20 yr may be due to changes in salinity. In the Bothnian Sea, the bottom layer salinity is significantly lower now. One pos- 
sibility for the observed changes in abundances across the whole Baltic Sea could be that part of the northern population has shifted southwards where salinity is higher and temperature is still low enough to sustain reproduction.

If Mertensia ovum has been misidentified over $20 \mathrm{yr}$ there is a possibility that the species is an arctic relict that has been in the Baltic for a much longer time even from the last saline water phases (Littorina, Yoldia Sea) of the sea, similar to many other marine taxa that otherwise are found in arcticsubarctic habitats only (e.g. Mysis mixta, Pontoporeia femorata; see Väinölä \& Hvilsom 1991). M. ovum may have adapted to temperate climate and brackish water with concomitant physiological adaptations, such as a decrease in body size and size at first reproduction. Related ecological and behavioural adaptations may include changes in timing of the population peak and vertical distribution patterns compared to the Arctic populations. To understand ecological and evolutionary significance of these adaptations and phenotypic differentiation, it is crucial to study the genetic relationship between the Baltic and the Arctic Mertensia populations.

Acknowledgements. We thank the crews of research vessels 'Aranda', 'Alkor', 'Baltica', 'Dana', 'Muikku', 'Salme' and 'Fyrbryggaren' for help during many samplings on various seasons, Leif Lundgren and Stefan Svensson (Stockholm University) for collecting samples, and 6 anonymous referees and the editors for comments on the manuscript. The study was financially supported by the Finnish Institute of Marine Research, Finnish Environment Institute, Nottbeck Foundation, EU 7th FP (FP/2007-2013) under BONUS programme: AMBER (Assessment and Modeling Baltic Ecosystem Response, grant no. 217246), BAZOOCA (Baltic Zooplankton Cascades), FORMAS contract no. 210-2008-1882, the project VECTORS (Vectors of Change in Oceans and Seas Marine Life, Impact on Economic Sectors, grant no. 266445), target financed project SF0180013s08 of the Estonian Ministry of Education and Research, Estonian Science Foundation grant 8254 and the Swedish national monitoring programme.

\section{LITERATURE CITED}

Ackefors H (1969) Ecological zooplankton investigations in the Baltic Proper 1963-1965. Ser Biol Inst Mar Res Lysekil Sweden 18:1-139

> Aranishi F, Okimoto T (2006) A simple and reliable method for DNA extraction from bivalve mantle. J Appl Genet 47:251-254

Baker LD, Reeve MR (1974) Laboratory culture of the lobate ctenophore Mnemiopsis mccradyi with notes on feeding and fecundity. Mar Biol 26:57-62

Blachowiak-Samolyk K, Søreide JE, Kwasniewski S, Sundfjord A, Hop H, Falk-Petersen S, Nøst Hegseth E (2008) Hydrodynamic control of mesozooplankton abundance and biomass in northern Svalbard waters $\left(79-811^{\circ} \mathrm{N}\right)$. Deep-Sea Res II 55:2210-2224

Bradtke K, Herman A, Urbanski JA (2010) Spatial and interannual variations of seasonal sea surface temperature patterns in the Baltic Sea. Oceanologia 52:345-362

Brotz L, Cheung WWL, Kleisner K, Pakhomov E, Pauly D (2012) Increasing jellyfish populations: trends in large marine ecosystems. Hydrobiologia 690:3-20

Collet D (1991) Modelling binary data. Chapman \& Hall, London

Condon RH, Graham WM, Duarte CM, Pitt KA and others (2012) Questioning the rise of gelatinous zooplankton in the world's oceans. Bioscience 62:160-169

Finenko GA, Kideys AE, Anninsky BE, Shiganova TA and others (2006) Invasive ctenophore Mnemiopsis leidyi in the Caspian Sea: feeding, respiration, reproduction and predatory impact on the zooplankton community. Mar Ecol Prog Ser 314:171-185

Gorokhova E, Lehtiniemi M, Viitasalo-Frösen S, Haddock SHD (2009) Molecular evidence for the occurrence of ctenophore Mertensia ovum in the northern Baltic Sea and implications for the status of the Mnemiopsis leidyi invasion. Limnol Oceanogr 54:2025-2033

Graeve M, Lundberg M, Böer M, Kattner G, Hop H, FalkPetersen S (2008) The fate of dietary lipids in the Arctic ctenophore Mertensia ovum (Fabricius 1780). Mar Biol 153:643-651

> Graham WM, Pagés F, Hamner WM (2001) A physical context for gelatinous zooplankton aggregations: a review. Hydrobiologia 451:199-212

Grant C, Olney JE (1979) Lower Bay zooplankton monitoring program: an introduction to the program and results of the initial survey of March 1978. Special scientific report no 93. Virginia Institute of Marine Science, The College of William and Mary, Gloucester Point, VA (http: //web.vims.edu/GreyLit/VIMS/ssr093.pdf)

Hansson HG (2006) Ctenophores of the Baltic and adjacent Seas - the invader Mnemiopsis is here! Aquat Invasions $1: 295-298$

Jaspers C, Haraldsson M, Bolte S, Reusch TBH, Thygesen UH, Kiørboe T (2012) Ctenophore population recruits entirely through larval reproduction in the central Baltic Sea. Biol Lett 8:809-812

Javidpour J, Molinero JC, Lehmann A, Hansen T, Sommer U (2009) Annual assessment of the predation of Mnemiopsis leidyi in a new invaded environment, the Kiel Fjord (Western Baltic Sea): a matter of concern? J Plankton Res 31:729-738

Kober KM, Nichols SA (2007) On the phylogenetic relationships of hadromerid and poecilosclerid sponges. J Mar Biol Assoc UK 87:1585-1598

Kremer P (1976) Population dynamics and ecological energetic of a pulsed zooplankton predator, the ctenophore Mnemiopsis leidyi. In: Wiley ML (ed) Estuarine processes, Vol 1. Academic Press, New York, NY, p 197-215

Laine AO, Sandler H, Andersin AB, Stigzelius J (1997) Longterm changes of macrozoobenthos in the Eastern Gotland Basin and the Gulf of Finland (Baltic Sea) in relation to the hydrographical regime. J Sea Res 38:135-159

> Lehtiniemi M, Pääkkönen JP, Flinkman J, Katajisto T and others (2007) Distribution and abundance of the American comb jelly (Mnemiopsis leidyi) - a rapid invasion to the northern Baltic Sea during 2007. Aquat Invasions 2: 445-449 
Lehtiniemi M, Lehmann A, Javidpour J, Myrberg K (2012) Spreading and physico-biological reproduction limitations of the invasive American comb jelly Mnemiopsis leidyi in the Baltic Sea. Biol Invasions 14:341-354

Lundberg M, Hop H, Eiane K, Gulliksen B, Falk-Petersen S (2006) Population structure and accumulation of lipids in the ctenophore Mertensia ovum. Mar Biol 149: 1345-1353

Martindale MQ (1987) Larval reproduction in the ctenophore Mnemiopsis mccradyi (order Lobata). Mar Biol 94: 409-414

Matsumoto GI (1991) Functional morphology and locomotion of the Arctic ctenophore Mertensia ovum (Fabricius) (Tentaculata: Cydippids). Sarsia 76:177-185

Mielck W (1926) Die Verbreitung der grösseren Planktontiere in der Ostsee, April 1925. Ber Dtsch Wiss Komm Meeresf 2:299-303

Mielck W, Künne C (1935) Fischbrut- und Planktonuntersuchungen auf dem R.F.D. 'Poseidon' in der Ostsee, Mai-Juni 1931. Wiss Meeresunters Abt Helgoland 19: $1-120$

Moran AL, Woods HA (2012) Why might they be giants? Towards an understanding of polar gigantism. J Exp Biol 215:1995-2002

Mutlu E, Bingel F, Gücü AC, Melnikov VV, Niermann U, Ostr NA, Zaika VE (1994) Distribution of the new invader Mnemiopsis sp. and the resident Aurelia aurita and Pleurobrachia pileus populations in the Black Sea in the years 1991-1993. ICES J Mar Sci 51:407-421

Potts JM, Elith J (2006) Comparing species abundance models. Ecol Model 199:153-163

Purcell JE, Shiganova TA, Decker MB, Houde ED (2001) The ctenophore Mnemiopsis in native and exotic habitats: U.S. estuaries versus the Black Sea basin. Hydrobiologia 451:145-176

Purcell JE, Hopcroft RR, Kosobokova KN, Whitledge TE (2010) Distribution, abundance, and predation effects of epipelagic ctenophores and jellyfish in the western Arctic Ocean. Deep-Sea Res II 57:127-135

Raskoff KA, Purcell JE, Hopcroft RR (2005) Gelatinous zooplankton of the Arctic Ocean: in situ observations under the ice. Polar Biol 28:207-217

Reeve MR, Walter MA, Ikeda T (1978) Laboratory studies of ingestion and food utilization in lobate and tentaculate ctenophores. Limnol Oceanogr 23:740-751

Remane A, Schlieper C (1971) Biology of brackish water, 2nd edn (Die Binnengewässer Vol 25). Schweizerbart, Stuttgart; Wiley, New York, NY

Editorial responsibility: Christine Paetzold, Oldendorf/Luhe, Germany
Richardson AJ, Bakun A, Hays GC, Gibbons MJ (2009) The jellyfish joyride: causes, consequences and management responses to a more gelatinous future. Trends Ecol Evol 24:312-322

Riisgård HU, Madsen CV, Barth-Jensen C, Purcell JE (2012) Population dynamics and zooplankton-predation impact of the indigenous scyphozoan Aurelia aurita and the invasive ctenophore Mnemiopsis leidyi in Limfjorden (Denmark). Aquat Invasions 7:147-162

Schaber M, Haslob H, Huwer B, Harjes A and others (2011) The invasive ctenophore Mnemiopsis leidyi in the central Baltic Sea: seasonal phenology and hydrographic influence on spatio-temporal distribution patterns. J Plankton Res 33:1053-1065

Schneider G (1987) Role of advection in the distribution and abundance of Pleurobrachia pileus in Kiel Bight. Mar Ecol Prog Ser 41:99-102

Siferd TD, Conover RJ (1992) Natural history of ctenophores in the Resolute Passage area of the Canadian High Arctic with special reference to Mertensia ovum. Mar Ecol Prog Ser 86:133-144

Swanberg N, Båmstedt U (1991) The role of prey stratification in the predation pressure by the cydippid ctenophore Mertensia ovum in the Barents Sea. Hydrobiologia 216-217:343-349

Väinölä R, Hvilsom MM (1991) Genetic divergence and a hybrid zone between Baltic and North Sea Mytilus populations (Mytilidae: Mollusca). Biol J Linn Soc 43: $127-148$

> Viitasalo S, Lehtiniemi M, Katajisto T (2008) The invasive ctenophore Mnemiopsis leidyi overwinters in high abundances in the subarctic Baltic Sea. J Plankton Res 30: 1431-1436

Vinogradov ME, Shushkina EA, Anokhina LL, Vostokov SV, Kucheruk NV, Lukashova TA (2000) Mass development of the ctenophore Beroe ovata Eschscoltz near the northeastern coast of the Black Sea. Oceanology (Mosc) 40: 52-55 (Engl transl)

Vuorinen I (1987) Is the ctenophore Pleurobrachia pileus important in the ecosystem of the Bothnian Sea? Memo Soc Fauna Flora Fenn 63:91-96

Vuorinen I, Vihersaari S (1989) Distribution and abundance of Pleurobrachia pileus (Ctenophora) in the Baltic Sea. Memo Soc Fauna Flora Fenn 65:129-131

> Welsh AH, Cunningham RB, Donnelly CF, Lindenmayer DB (1996) Modelling the abundance of rare species: statistical models for counts with extra zeros. Ecol Model 88: 297-308

Submitted: December 7, 2011; Accepted: July 1, 2013 Proofs received from author(s): September 13, 2013 